\title{
Prebiotic Potential of underutilized Jerusalem artichoke in Human Health: A Comprehensive Review
}

\author{
Diksha Gupta $^{1 *}$ and Neelam Chaturvedi
}

\author{
${ }^{1}$ Research scholar, ${ }^{2}$ Associate professor, Department of Food Science and Nutrition, Banasthali Vidyapith, Dist-Tonk, Rajasthan, India \\ (304022) \\ E-mail: dikshagupta823@gmail.com
}

\begin{abstract}
The global burden of non-communicable diseases has been rising over the last century, with the leading cause of neurological, metabolic and degenerative disorders. The several studies have reported that the incorporation of prebiotics in human diet is favourable to eliminate the pathological ailments. Since prebiotics occur naturally in plants including leeks, asparagus, onion, wheat, garlic, chicory, oats, soybean and Jerusalem artichoke. Jerusalem artichoke is a perennial tuber contains proteins, mono or poly- unsaturated fatty acids, vitamins, minerals and excellent amount of soluble dietary fibers such as inulin and fructo-oligosaccharides with negligible amount of starch which is digested with Bifidobacterium. It is associated with expansion of bioavailability of minerals, increase activity of favourable bacteria, ease the digestion of high protein diets, delay fat absorption, deliver roughage, prevent constipation, increase satiety value which results in various therapeutic properties such as antidiabetic, cardioprotective and hepatoprotective effects, anti-inflammatory, antimicrobial, anti-obesity, anti-inflammatory and other pharmacological properties. It is also used as a functional food ingredient in the design and production of child formulation, chocolates, sugar confectionaries, soups, sauces, meat products, bakery products, nutritional bars, beverages, milk products, dietary supplements and many other food products. Therefore, its remarkable therapeutic effects and various food applications make this tuber very valuable for further investigation in the area of pharmaceutical and food industries.
\end{abstract}

Keywords-Jerusalem artichoke, Prebiotics, Inulin, Fructo-oligosaccharides, Pharmacological properties.

\section{INTRODUCTION}

Nowadays, besides the basic role of nutrition entailing in the supply of nutrients for growth and development, additional aspects are becoming increasingly significant, including the maintenance of health and counteracting diseases. The global burden of non-communicable diseases has been rising over the last century, with the leading cause of neurological, metabolic and degenerative disorders. The several studies have reported that the incorporation of prebiotics in human diet is favourable to eliminate these pathological conditions (Markowiak and Katarzyna, 2017). Prebiotics are non-digestible oligosaccharides and polysaccharides that positively stimulating the growth and/or activity of bifidobacteria and lactic acid bacteria in the colon. They exert antagonism against Salmonella sp. and Escherichia coli, limiting their proliferation, therefore, improve host health
(Bindels, et al., 2015). Prebiotics are occurring naturally in plants such as leeks, asparagus, onion, wheat, garlic, chicory, oats, soybean and Jerusalem artichoke and synthesized from enzymatic digestion of polysaccharides. Scientists have re-examined and classified prebiotics on the basis of common criteria in which, Inulin, fructoseoligosaccharides, galactosaccharides, lactulose and polydextose are recognized as the establishing prebiotics. On the other hand, isomalto-oligosaccharides, xylooligosaccharides and lactitol are categorized as emerging prebiotics (Sadler and Stowell, 2007). They exert a myriad of health promoting effects including; they are involved in formulating starter culture, maintain intestinal health, inhibiting cancer and preventing metabolic disorders. They also seem to promote a positive modulation of immune system as shown in Figure 1 (Delgado, et al., 2011). 


\begin{tabular}{|c|c|c|c|c|c|}
\hline \multirow{4}{*}{$\begin{array}{l}\text { Prebiotics (Inulin } \\
\text { and Fructo- } \\
\text { oligosaccharides) }\end{array} \rightarrow$} & $\underline{\text { Food sources }}$ & & $\begin{array}{c}\text { Intestinal microbiota } \\
\text { changes }\end{array}$ & $\rightarrow$ & $\begin{array}{l}\text { Positive effect on development of } \\
\text { beneficial intestinal bacterial }\end{array}$ \\
\hline & $\begin{array}{c}\text { Jerusalem } \\
\text { artichoke, } \\
\text { leeks }\end{array}$ & $\longrightarrow$ & $\begin{array}{l}\text { Carcinogenesis } \\
\text { inhibition }\end{array}$ & $\longrightarrow$ & $\begin{array}{l}\text { Reduce risk of colorectal cancer } \\
\text { and other tumors }\end{array}$ \\
\hline & $\begin{array}{c}\text { asparagus, } \\
\text { onion, wheat, } \\
\text { garlic, chicory, } \\
\text { oats }\end{array}$ & $\longrightarrow$ & $\begin{array}{l}\text { Pathogen inhibition } \\
\text { Immunomodulation }\end{array}$ & $\rightarrow$ & $\begin{array}{l}\text { Protection against infection } \\
\text { Support the immune system }\end{array}$ \\
\hline & & $\rightarrow$ & $\begin{array}{l}\text { Nutrient absorption } \\
\text { effects }\end{array}$ & $\longrightarrow$ & $\begin{array}{c}\text { Reduced risk of metabolic } \\
\text { syndrome (Diabetes, cardiovascular } \\
\text { diseases and obesity) }\end{array}$ \\
\hline
\end{tabular}

Fig.1: Mechanism of prebiotics and their effects

\section{JERUSALEM ARTICHOKE}

Jerusalem artichoke, a sunflower species belongs to Asteraceae family is botanically known as Helianthus tuberosus L. The stem is 5-10 ft tall, ridged and stout which can become woody over time. The leaves are situated near the top of the stem and flowers are small and bright yellow (Pan, et al., 2009). It has an underground rhizome system which bears uneven and elongates varying from knobby to round clusters small fleshy tubers resembling to potatoes. The colour of tubers varies from pale brown, red and purple depending upon the climate conditions (Talipova, 2001). These tubers originated from the United States that become naturalized as an economic crop worldwide in temperate areas and is presently also grown in Canada, France, Germany, Netherlands, USSR, Japan and India (Slimestad, et al., 2010).

Jerusalem artichoke tuber contains proteins, mono or polyunsaturated fatty acids, vitamins, minerals and dietary fibres with negligible amount of starch (Barta and Patkai, 2007). Its tubers have functional food ingredients such as inulin and fructo-oligosaccharides contributing nutraceutical properties (Kays and Nottingham, 2007). According to Barclay, et al., (2010) that artichoke tubers contain $10-20 \%$ of inulin on fresh weight basis and known to have prebiotic effects. Similarly, El-Kholy and Mahrous, (2015) stated that the aqueous extract of Jerusalem artichoke tubers contains higher amount of inulin $(21.46 \mathrm{~g} / 100 \mathrm{~g})$ and three major sugars: sucrose $(4.33 \mathrm{~g} / 100 \mathrm{~g})$, fructose $(3.25 \mathrm{~g} / 100 \mathrm{~g})$ and glucose $(2.77 \mathrm{~g} / 100 \mathrm{~g})$. It has high amount of biologically active components including sesquiterpenes, flavonoids, isoflavonoids, phenols, phenolic acids, glycoalkaloids, phytic acids, coumarins, organic acids, polyacetylenes, and their derivatives naturally occurring isomers of caffeoylquinic acid. It also possesses antidiabetic, antiinflammatory, antimicrobial, anti-obesity, anticancer and other pharmacological properties (Kapusta, et al., 2013).

\section{PREBIOTIC COMPONENTS IN JERUSALEM ARTICHOKE}

\section{INULIN}

Inulin is a plant polysaccharide that comprises all straightchain fructans consisting of fructosyl units linked by $\beta$ $\mathrm{D}(2-1)$ glycosidic bond (Roberfroid, 2005). It is a polydisperse mixture of molecules which can be symbolized by as GFn, where G is the glucosyl moiety, F is the fructosyl moiety and $\mathrm{n}$ is the number of fructosyl moiety linked by $\beta(2-1)$ linkages. The degree of polymerization of inulin typically ranges from 2 to 60 as shown in Figure 2. The presence of $\beta(2-1)$ bond prevents inulin from being digested like typical carbohydrate and is responsible for its reduced calorie value and dietary fibre effects (Abed, et al., 2016).

Inulin is a "functional food ingredient" and known to have prebiotic potential, which is associated with expanding bioavailability of minerals, inhibition of pathogenic bacteria and increase activity of beneficial bacteria in the digestive tract. It also ease the digestion of high protein diets, deliver roughage, prevent constipation, delay fat absorption, increase satiety value without having extra calories which results in lowering blood glucose, cholesterol and triglycerides levels (Lopez-Molina, et al., 2005). 


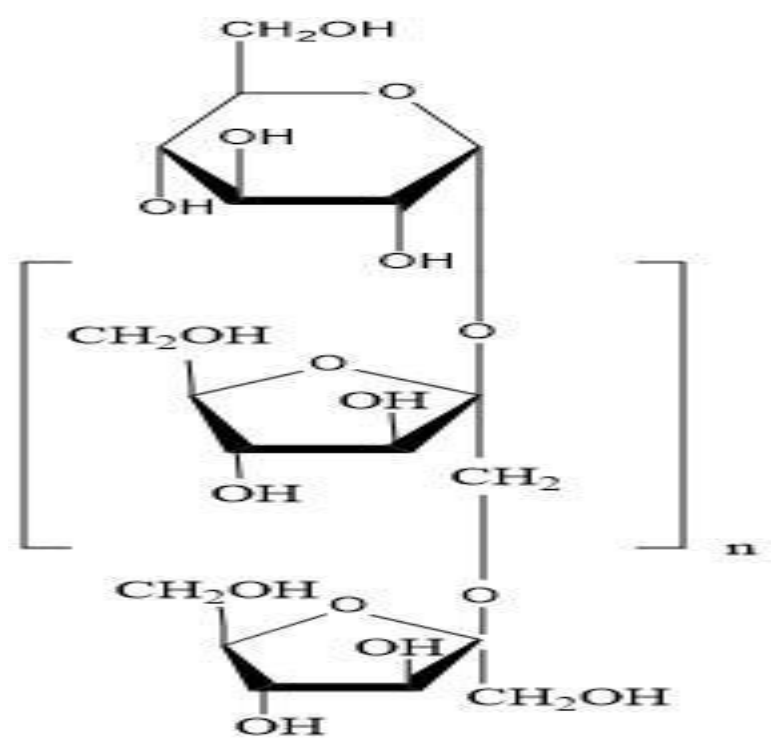

Fig.2: Structure of inulin, $n=2-60$

\section{FRUCTO-OLIGOSACCHARIDES (FOS)}

Fructo-oligosaccharides (FOS), also known as "oligofructan and oligofructose" that are naturally present in vegetables and fruits (Muir, et al., 2009). They are short chain of fructose polymer which are composed of Dfructose units linked with $\beta(2-1)$ and not hydrolysed by human digestive enzymes. They are obtained from the hydrolysis of inulin using endoinulinase enzyme or by conducting enzymatic reaction of sucrose transfructosylation residues using the $\beta$ fructofuranosidase or fructosyl- transferase (De-Sousa, et al., 2011). Ketose $\left(\mathrm{GF}_{2}\right)$, nystose $\left(\mathrm{GF}_{3}\right)$ and fructofuranosyl nystose $\left(\mathrm{GF}_{4}\right)$ are the three key chemical structures of FOS, in which the fructose units (F) are linked at $\beta(2-1)$ glycosidic bonds and the terminal glucose units $(\mathrm{G})$ are linked to fructose unit at the $\alpha(1-2)$ glycosidic bond as shown in Figure 3 (Ibrahin, 2018).

FOS can be used as a substitute for sucrose in foods such as, yogurt, nutritional bars, diet beverages and in low calorie sweetener for diabetes. They are claimed to enhance the growth of favourable bacteria in the colon and used as soluble dietary fibre for constipation and traveler's diarrhoea (Costa, et al., 2015). It is associated with Improving mineral absorption (calcium and magnesium), lowering of blood pressure and responsible for the inhibition of the production of the reductase enzyme that contribute to cancer (Coundray, et al., 2003). It also prevents obesity, stimulates the immune system, reduce the synthesis of triglycerides and fatty acids in the liver and decrease blood glucose levels (Kolida and Gibson, 2007). Table 1 illustrates the amount of inulin and fructooligosaccharides present naturally in plants such as Jerusalem artichoke leeks, asparagus, onion, wheat, garlic, chicory, oats and soybean (Thammarutwasik et al., 2009).
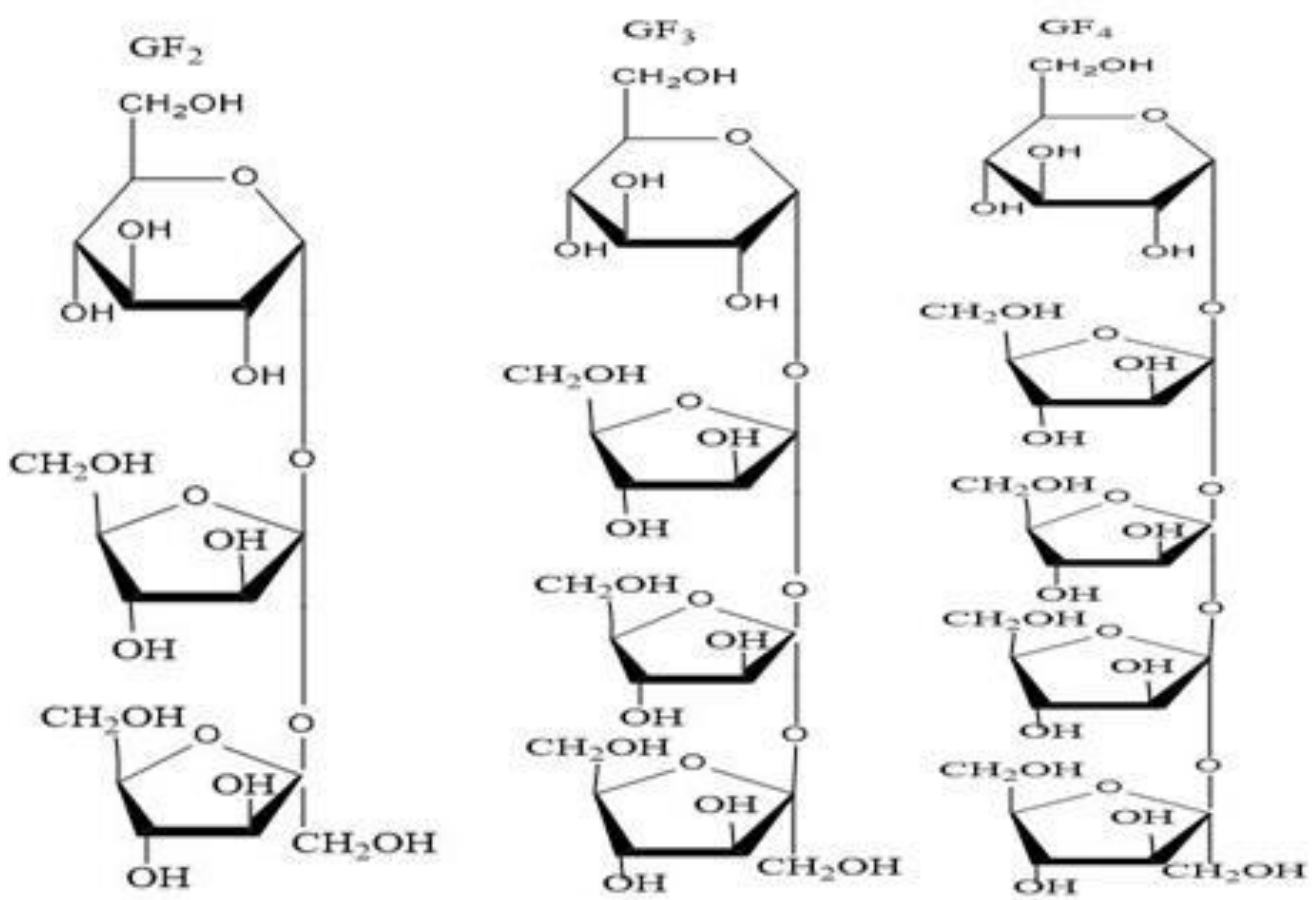

Fig.3: Structure of fructo-oligosaccharides 
Table 1: Inulin and fructo-oligosaccharides content of food products

\begin{tabular}{|c|c|c|}
\hline Food Sources & $\begin{array}{c}\text { Inulin } \\
(\mathbf{g} / \mathbf{1 0 0 g})\end{array}$ & $\begin{array}{c}\text { Fructo-oligosaccharides } \\
(\mathbf{g} / \mathbf{1 0 0 g})\end{array}$ \\
\hline Jerusalem artichoke tuber (Helianthus tuberosus $)$ & $\mathbf{1 6 . 0 - 2 0 . 0}$ & $\mathbf{1 0 - 1 5}$ \\
\hline Raw onion pulp (Allium cepa) & $1.1-7.5$ & $2.0-6.0$ \\
\hline Asparagus raw (Asparagus officinalis) & $2.0-3.0$ & $5.0-10$ \\
\hline Chicory root (Cichoriumintybus) & $35.7-47.6$ & $5.0-10$ \\
\hline Barley (raw cereal) (Hordeumvulgare) & $0.5-1.5$ & $0.5-1.5$ \\
\hline Wheat (flour baked) (Titicum sp.) & $1.0-3.8$ & $1.0-3.8$ \\
\hline Garlic (Allium sativum) & $9.0-16.0$ & $3.0-6.0$ \\
\hline Leek (Allium ampeloprasum) & $3-10$ & $2-5$ \\
\hline Banana (Musa sapientum) & $0.3-0.7$ & $0.3-0.7$ \\
\hline Yacon (Smallanthus sonchifolius) & $3-19$ & $3-19$ \\
\hline Artichoke (Cynara scolymus) & $3-10$ & $<1$ \\
\hline Dandelions (Taraxacum officinale) & $12-15$ & $\mathrm{NA}$ \\
\hline Rye (Secale cereale) & $0.5-1.0$ & $0.5-1.0$ \\
\hline
\end{tabular}

\section{FOOD APPLICATIONS OF JERUSALEM ARTICHOKE}

Currently, one of the trends in food segment is the health and wellness linked with the growth of food industry. Formulation of functional foods containing prebiotic component is widely used in the design of numerous dietary and pharmaceutical supplements in recent years, not only for economic reasons but by scientific evidence of its remunerations (Burgain, et al., 2011). Hence, Jerusalem artichoke as a source of inulin and fructoseoligosaccharides, have been incorporated into a wide variety of food products. It is used as a functional food ingredient in the design and production of child formulation, chocolates, sugar confectionaries, soups, sauces, nutritional bars, meat products, bakery products, beverages and drinks, yoghurts, desserts, milk products, dietary supplements and many other food products as depicted in Table 2 (Wang, 2009). Though, consumers may appreciate tasty food while promoting beneficial effects to their own health (Coman, et al., 2012). According to Millani, et al., (2009) consumption of child formulations incorporated with these agents is associated with improving allergy cases and preventing constipation. Radovanovic, et al., (2014) conducted that wheat bread fortified with Jerusalem artichoke powder have optimal nutritional value with low Glycemic index (53.70) and low Glycemic load (7.67). Likewise, Rodrigues, et al., (2012) reported that preparation of cheese with inulin and fructooligosaccharides is associated with lower atherogenecity index.
Table 2: Application of Jerusalem artichoke in food products

\begin{tabular}{|l|l|}
\hline Food Products & \multicolumn{1}{|c|}{ Applications sugar } \\
\hline $\begin{array}{l}\text { Beverages and } \\
\text { drinks }\end{array}$ & $\begin{array}{l}\text { Mouthfeel, foam } \\
\text { replacement, fre abilization and prebiotics } \\
\text { stand }\end{array}$ \\
\hline $\begin{array}{l}\text { Yoghurts and } \\
\text { desserts }\end{array}$ & $\begin{array}{l}\text { Texture and mouthfeel, sugar } \\
\text { replacement, fiber and } \\
\text { prebiotics }\end{array}$ \\
\hline Meat products & $\begin{array}{l}\text { Texture stability, fat } \\
\text { replacement, and fiber }\end{array}$ \\
\hline $\begin{array}{l}\text { Breads and } \\
\text { fillings }\end{array}$ & $\begin{array}{l}\text { Texture, sugar or fat } \\
\text { replacement, fiber and } \\
\text { prebiotics }\end{array}$ \\
\hline Cake and biscuits & $\begin{array}{l}\text { Moisture retention, sugar } \\
\text { replacement, fiber and } \\
\text { prebiotics }\end{array}$ \\
\hline $\begin{array}{l}\text { Dietary } \\
\text { supplements }\end{array}$ & $\begin{array}{l}\text { Sugar or fat replacement, } \\
\text { fiber and prebiotics }\end{array}$ \\
\hline $\begin{array}{l}\text { Child } \\
\text { formulations }\end{array}$ & $\begin{array}{l}\text { Body and mouthfeel, texture, } \\
\text { fiber, stability and prebiotics }\end{array}$ \\
\hline $\begin{array}{l}\text { Sugar } \\
\text { confectionaries }\end{array}$ & $\begin{array}{l}\text { Sugar replacement, fiber and } \\
\text { prebiotics }\end{array}$ \\
\hline Chocolate & $\begin{array}{l}\text { Sugar replacement, heat } \\
\text { resistance and fiber }\end{array}$ \\
\hline Soups and sauces & $\begin{array}{l}\text { Sugar replacement and } \\
\text { prebiotics }\end{array}$ \\
\hline
\end{tabular}

THERAPEUTIC PROSPECTIVE OF JERUSALEM ARTICHOKE AS FUNCTIONAL FOOD INGREDIENT ANTIDIABETIC PROPERTIES

There is evidence that soluble fibres are beneficial in the reduction of serum glucose and insulin postprandial by 
raising the viscosity of the nutrients in the small intestine that results in delaying the release of glucose (Saad, 2006). Oral administration of Jerusalem artichoke tuber extracts caused a significant decrease in blood glucose levels by $33.8 \%$ in hyperglycemic rats due to the presence of an optimum quantity of polysaccharide inulin (Asian, et al., 2010). Similarly, Al, et al., (2012) elucidated that diets fortified with artichoke tuber induced a significant decrease in serum glucose in the hyperglycemic rats. Wang, et al., (2016) reported that fermented Jerusalem artichoke extract showed significant decrease in blood glucose concentration and serum insulin level in mice. In support of these observations, Okada, et al., (2017) also reported that Jerusalem artichoke tubers improve glucose tolerance in rats. Likewise, Ahn, et al., (2018) revealed that Supplementation of Jerusalem artichoke has been associated with reduced level of fasting glucose and homeostasis model assessment insulin resistance of diabetic patients.

\section{CARDIOPROTECTIVE PROPERTIES}

The pronounced decrease occurred in serum total cholesterol, triglycerides, LDL and VLDL in rats fed with Jerusalem artichoke tuber compared with the positive control (Zaky, 2009). Likewise, Gaafar, et al., (2010) stated that supplementation of inulin extracted from artichoke tubers resulted in a decrease in total cholesterol, triglycerides, total lipids, LDL and VLDL-cholesterol levels in diabetic rats. Meanwhile, HDL level was increased significantly. In addition, Asma and Gindy, (2016) have shown that bread substituted with Jerusalem artichoke powder, barley flour and a mixture of both induced significant decrease in triglycerides, total cholesterol and LDL- cholesterol of rats in the hyperglycemic groups in comparison with control group.

\section{HEPATOPROTECTIVE PROPERTIES}

The study stated by Ghanem, et al., (2016) concluded that the supplementation of low calorie pan breads containing Jerusalem artichoke as a source of inulin showed significant decrease in Glutamate oxaloacetate transaminase and Glutamate pyruvate transaminase enzyme level in diabetic mice when compared with control group. Kim and Han, (2013) concluded that the aqueous extract of Jerusalem artichoke prevented elevation of aminotransferase, alanine aminotransferase, serum aspartate, y-glutamyl transpeptidase and lactate dehydrogenase levels in STZ-induced diabetic rats. Another result revealed by Yang, et al., (2012), that artichoke tubers may improve hepatic insulin sensitivity, decreases the synthesis of fatty acids and triglycerides in liver and lowers their circulating level in mice. Later, Abdel-Hamid, et al., (2015) concluded that Jerusalem artichoke tubers showed a promising hepatoprotective effect against CCL4 (Carbon tetrachloride)-induced fibrosis via modulation of apoptotic signaling and fibrogenic activity.

\section{ANTIOBESITY PROPERTIES}

According to Kaur and Gupta, (2002) that inulin is a low calorie food ingredient as it comprises less than half amount of calorie content of digestible carbohydrates. Cho, et al., (2010) revealed that the supplementation with Jerusalem artichoke tuber exerted the antiobesity effects in the diet of obese rats due to the presence of dietary fibres, rendering a good source for preventing obesity. Later, Guess, et al., (2015) concluded that human subjects supplemented with inulin lost significantly more weight and had lower hepatic muscle fat content compared to control.

\section{ANTI-INFLAMMATORY PROPERTIES}

Diets fortified with inulin suppress $G$ protein-coupled receptor-43 overexpression which combat high-fat-dietinduced obesity through the modification of the gut microbiota and resulted in decreased level of circulating lipopolysaccharide and lower C-reactive protein levels to attenuate inflammation (Dewulf, et al., 2013). According to Koleva et al., (2012) administration of inulin and fructooligosaccharides attenuate chronic intestinal inflammation in HLA-B27 transgenic rats. Hence, administration of Jerusalem artichoke might reduce systemic inflammation due to the presence of fructo-oligosaccharides and inulin.

\section{ANTIMICROBIAL PROPERTIES}

The administration of artichoke as a source of soluble fibers increase the number of lactobacilli, bifidobacteria, and certain butyrate-producing bacteria such as Clostridium perfringens group (Costabile, et al., 2010). Likewise, the study showed that its extracts exerted antifungal activity against Rhizoctoniasolani, Botrytis cinerea and Alternariasolani (Liu, et al., 2007). Gengaihi, et al., (2009) reported that tuber extracts have antimicrobial activity against the test gram-positive (Candida albo, Pseudomonas, Bacillus subtilis and Staphylococcus aureus) and gram-negative bacteria (Saccharomyces cerevisiae, Arthrobacter, Kill bacteria tiffy, Escherichia coli, and Enterobacter due to the presence of many potent compounds such as bitter sesquiterpene, lactones, inulin, flavonoids and coumarins.

\section{CONCLUSION}

The review paper revealed that Jerusalem artichoke tuber as prebiotic agent appears to be unique among the currently available adaptogenic tubers. It possesses antidiabetic, cardioprotective and hepatoprotective effects, antiobesity, anti-inflammatory, antimicrobial and many 
other pharmacological properties. Its powder has been used in numerous dietary supplements such as child formulation, chocolates, sugar confectionaries, soups, sauces, nutritional bars, meat products, bakery products, beverages, milk products and many other products in food industry. Hence, its remarkable therapeutic effects and various food applications make this tuber very valuable for further investigation in the area of pharmaceutical and food industries.

\section{REFERENCES}

[1] Abdel- Hamid N, Nazmy MH, Wahid A, Abdel-Moniem M. Jerusalem artichoke attenuates experimental hepatic fibrosis via modulation of apoptotic signalling and fibrogenic activity. Biochem Biotechnol Res 2015; 3(3):4350 .

[2] Abed S, Ali AH, Nowan A, Sobianiazi, Al-Fargaammar, Bakry AM. Inulin as prebiotics and its applications in food industry and human health: A review. Int J Agric Innov Res 2016; 5(1)

[3] Ahn HY, Kim M, Seo CR, Yoo HJ, Lee SH, Lee JH. The effects of Jerusalem artichoke and fermented soyabean powder mixture supplementation on blood glucose and oxidative stress in subjects with prediabetes or newly diagnosed type 2 diabetes. Nutr Diabetes 2008; 8(1):1-13.

[4] Al SH, Sarwat MI, El-Tobgy KM, Abd EI, Alem MS. Jerusalem artichoke tubers, onion and hulless barley as functional foods in alloxan Induced diabetic rats. J Appl Sci Res 2012; 8(2):1328-1336.

[5] Asian M, Orhan DD, Ergun F. Hypoglycemic activity and antioxidant potential of some medicinal plants traditionally used in turkey for diabetes. J Ethanopharmocol 2010; 128(2):384-389.

[6] Asma A, Gindy EI. (2016). Technological and biological studies on Jerusalem artichoke and barley. Eur J Food Sci Technol 2016; 4:1-15.

[7] Barclay TG, Ginic-Markovoic M, Cooper PD, Petrovsky N. Inulin: A versatile polysaccharide with multiple pharmaceutical and food chemical uses. J Excip Food Chem 2010; 1(3):27-50.

[8] Barta J, Patkai G. Chemical composition and storability of Jerusalem artichoke tubers. Acta Aliment 2007; 36(2):257267.

[9] Bindels LB, Delzenne NM, Cani PD, Walter J. Towards a more comprehensive concept for prebiotics. Nat Rev Gastro Hepat 2015; 12(5):303-310.

[10] Burgain J, Gaiani C, Linder M, Scher J. Encapsulation of probiotic living cells: From laboratory scale to industrial applications. J Food Eng 2011; 104(4):467-483.

[11] Cho KD, Kim EJ, Kim MY, Kim JS, Han CK, Lee BH. Antiobesity and antidiabetic effects of Jerusalem artichoke and purple sweet potato in the diet induced obese rats. Nutrition 2010; 24:722-723.

[12] Coman MM, Cecchini C, Verdenelli MC, Silvi S, Orpianesi C, Cresci A. Functional foods as carriers for SYNBIO ${ }^{\circledR}$, a probiotic bacteria combination. Int J Food Microbiol 2012; 157(3):346-352.

[13] Costa GT, Abreu GC, Guimaraes AB, Vasconcelos PR, Guimaraes SB. Fructo-oligosaccharide effects on serum cholesterol levels: An overview. Acta Cir Bras 2015; 30(5):366-370.

[14] Costabile A, Kolida S, Klinder A, Gisti E, Baueriein M, Frohbrug C, et al. A double blind, placebo-controlled, cross over study to establish the bifidogenic effect of a very long chain inulin extracted from globe artichoke (Cynara scolymus) in healthy subjects. Br J Nutr 2010; 104:10071017.

[15] Coundray C, Demigne C, Rayssiguier Y. Effects of dietary fiber on magnesium absorption in animals and humans. $\mathrm{J}$ Nutr 2003; 133(1):1-4.

[16] Delgado GTC, Tamashiro WMSC, Junior MRM, Moreno YMF, Pastore GM. The putative effects of prebiotics as immunomodulatory agents. Food Res Int 2011; 44(10):3167-3173.

[17] De-Sousa VMC, Dos-Santos EF, Sgarbieri VC. The importance of prebiotics in functional foods and clinical practice. Food Nutr Sci 2011; 2:133-144.

[18] Dewulf EM, Cani PD, Claus SP, Fuentes S, Puylaert PG, Neyrinck AM, et al. Insight into the prebiotic concept: Lessons from an exploratory, double blind intervention study with inulin-type fructans in obese women. Gut 2013; 62(8):1112-1121.

[19] El-Kholy WM, Mahrous H. Biological studies on bioyoghurt fortified with prebiotics obtained from Jerusalem artichoke. Food Nutr Sci 2015; 6(16):1552-1564.

[20] Gaafar AM, Serag EI-Din MF, Boudy EA, EI-Gazar HH. Extraction condition of inulin from Jerusalem artichoke tubers and its effects on blood glucose and lipid profile in diabetic rats. J Am Sci 2010; 6(5):36-43.

[21] Gengaihi SAEI, Aboul Enein AM, Abou Elalla FM, Abou Baker DH. Molecualr characterization and antimicrobial activities of chicory and Jerusalem artichoke plants. Int $\mathrm{J}$ Acad Res 2009; 1(2):66-71.

[22] Ghanem SM, Ibrahium MI, Saed B. Effect of low calorie pan bread containing wheat bran and some vegetables flours on biological properties of diabetic rats. Middle East J Appl Sci 2016; 6:315-328.

[23] Guess ND, Dornhorst A, Oliver N, Bell JD, Thomas EL, Frost GS. A randomized control trial: the effect of inulin on weight management and ectopic fat in subjects with prediabetics. Nutr Metab 2015; 12(36):2-10.

[24] Ibrahim OO. Functional oligosaccharides: Chemicals structure, manufacturing, health benefits, applications and regulations. J Food Chem Nanotechnol 2018; 4(4):65-76.

[25] Kapusta I, Krok ES, Jamro DB, Cebulak T, Kaszuba J, Salach RT. Identification and quantification of phenolic compounds from Jerusalem artichoke (Helianthus tuberosus L.) tubers. J Food, Agric, Environ 2013; 11:601606.

[26] Kaur N, Gupta AK. Application of inulin and oligofructose in health and nutrition. J Biosci 2002; 27(7):703-714. 
[27] Kays SJ, Nottingham SF. Biology and chemistry of Jerusalem artichoke: Helianthus tuberosus L. Florida: CRC Press Boca Raton; 2007.

[28] Kim HS, Han GD. Hypoglycemic and hepatoprotective effects of Jerusalem artichoke extracts on streptozotocininduced diabetic rats. Food Sci Biotechnol 2013; 22(4):1121-1124.

[29] Koleva PT, Valcheva RS, Sun X, Ganzle MG, Dieleman LA. Inulin and fructo-oligosaccharides have divergent effects on colitis and commensal microbiota in HLA-B27 transgenic rats. Br J Nutr 2012; 108(9):1-11.

[30] Kolida S, Gibson GR. Prebiotic capacity of inulin type fructans. J Nutr 2007; 137(11):2503-2506.

[31] Liu HW, Liu ZP, Liu L, Zhao GM. Studies on the antifungal and chemical components of extracts from Helianthus tuberosus leaves. J Nat Prod Res Dev 2007; 19:405-409.

[32] Lopez-Molina D, Navarro-Martinez MD, Rojas-Melqarejo F, Hiner AN, Chazarra S, Rodrique-Lopez JN. Molecular properties and prebiotic effect of inulin obtained from artichoke (Cynara scolymus L.). Phytochemistry 2005; 66(12):1448-1476.

[33] Markowiak P, Slizewska K. Effects of probiotics, prebiotics, and synbiotics on human health. Nutrients 2017; 9(9):1-30.

[34] Millani E, Konstantyner T, Taddei JAAC. Effects of prebiotics (oligosaccharides) use on child's health. Rev Paul Pediatr 2009; 27(4):436-446.

[35] Muir JG, Rose R, Rosella O, Liels K, Barrett JS, Shepherd SJ, Gibson PR. Measurement of short chain carbohydrates in common Australian vegetables and fruits by highperformance chromatography (HPLC). J Agric Food Chem 2009; 57(2):554-565.

[36] Okada N, Kobayashi S, Moriyama K, Miyataka K, Abe S, Sato C, Kawazoe. Helianthus tuberosus (Jerusalem artichoke) tubers improve glucose tolerance and hepatic lipid profile in rats fed a high fat diet. Asia Pac J Trop Med 2017; 10(5):439-443.

[37] Pan L, Sinden MR, Kennedy AH, Chai H, Linda E, Watson LE, Graham TL, Kinghorn AD. Bioactive constituents of Helianthus tuberosus (Jerusalem artichoke). Phytochem Lett 2009; 2(1):15-18.

[38] Radovanovic AM, Milovanovic OZ, Kipic MZ, Ninkovic MB, Cupara SM. Characterization of bread enriched with Jerusalem artichoke powder content. J Food Nutr Res 2014; 2(12):895-898

[39] Roberfroid M. Introducing inulin-type fructan. Br J Nutr 2005; 93(1):13-25.

[40] Rodrigues D, Rocha-Santos TAP, Gomes AM, Goodfellow BJ, Freitas AC. Lipolysis in probiotic and symbiotic cheese: The influence of probiotic bacteria, prebiotic compounds and ripening time on free fatty acid profiles. Food Chem 2012; 131(4):1414-1421.

[41] Saad SMI. Probiotics and prebiotics: The state of the art Braz J Pharm Sci 2006; 42(1):1-16.

[42] Sadler M, Stowell JD. Calorie control and weight management. In K O’Donnell, MW Kearsley. Sweeteners and sugar alternatives in food technology. $2^{\text {nd }}$ ed. Blackwell Publishing Ltd; 2007. P. 77-88.

[43] Slimestad R, Seljaasen R, Meijer K, Skar SL. Norwegiangrown Jerusalem artichoke (Helianthus tuberosus L.): Morphology and content of sugars and fructooligosaccharides in stems and tubers. J Sci Food Agric 2010; 90(6):956-964.

[44] Talipova M. Lipids of Helianthus tuberosus L. Chem Nat Compd 2001; 37(3):213-215.

[45] Thammarutwasik P, Hongpattarakere T, Chantachum S, Kijroongrojana K, Itharat A, Reanmongkol W, Tewtraku S, Ooraikul B. Prebiotics - A review. Songklanakarin J Sci Technol 2009; 31(4):401-408.

[46] Wang Y. (2009). Prebiotics: Present and future in food science and technology. Food Res Intl 2009; 42(1):8-12.

[47] Wang Z, Hwang SH, Lee SY, Lim SS. Fermentation of purple Jerusalem artichoke extract to improve the $\alpha$ glucosidase inhibitory effect in vitro and ameliorate blood glucose in db/db mice. Nutr Res Pract 2016; 10(3):282-287.

[48] Yang HJ, Kwon DY, Kim MJ, Kang S, Kim DS, Park S Jerusalem artichoke and chung cooking and additively improve insulin secretion and sensitivity in diabetic rats. Nutr Metab 2012; 9(112):1-12.

[49] Zaky EA. Physiological response to diets fortified with Jerusalem artichoke tubers (Helianthus tuberosus L.) powder by Diabetic rats. Am Eurasian J Agric Environ Sci 2009; 5:682-688 